\title{
Pollutant bioaccumulation in anchovy (Engraulis encrasicolus) tissue, fish species of commercial interest at the Romanian Black Sea coast
}

\author{
Mădălina GALAȚCHI ${ }^{1,2, *}$, Andra $\operatorname{OROS}^{1}$, Valentina $\mathrm{COATU}^{1}$, Mioara $\mathrm{COSTACHE}^{3}$, Dragomir $\mathrm{COPREAN}^{2,4}$, \\ Liviu-Daniel GALAŢCHI ${ }^{2}$ \\ ${ }^{1}$ National Institute for Marine Research and Development Grigore Antipa, Bd. Mamaia nr. 300, RO-900581, \\ Constanţa 3, Romania \\ ${ }^{2}$ Faculty of Natural and Agricultural Sciences, Ovidius University of Constanta, Aleea Universitatii nr. 1, corpul \\ B, RO-90047, Constanta, Romania \\ ${ }^{3}$ Fish Culture Research and Development Station Nucet, Str. Principala nr. 549, RO-137335, Nucet, Dambovita, \\ Romania \\ ${ }^{4}$ Academy of Romanian Scientists, Splaiul Independentei nr. 54, Sector 5, Bucharest, Romania
}

\begin{abstract}
The pollution of the marine ecosystem is a world-wide problem. Heavy metals and organochlorine compounds are among the most harmful elemental pollutants and are of particular concern because of their toxicity to humans. Anchovy (Engraulis encrasicolus, Linnaeus 1758), small pelagic fish with a key ecological role in the marine food web, is an important link connecting the lower and upper trophic levels, being also a valuable species for human consumption. Thus, anchovy samples were collected from different stations along the Romanian Black Sea coast and the analyzed contaminants were organochlorine pesticides (OCPs), polychlorinated biphenyls (PCBs) and heavy metals $(\mathrm{Cd}, \mathrm{Pb}, \mathrm{Ni}, \mathrm{Cu}$ and $\mathrm{Cr}$ ) in muscle tissue. $\mathrm{Cd}$ and $\mathrm{Pb}$ are the heavy metals that exceeded the allowed levels under the EU legislation $(0.3 \mu \mathrm{g} / \mathrm{g}$ ), Cd recorded values within the range $0.29-0.51 \mu \mathrm{g} / \mathrm{g}$ (average $0.36 \pm 0.09 \mu \mathrm{g} / \mathrm{g}$ ) and $\mathrm{Pb}$ recorded values within the interval $0.29-1.62 \mu \mathrm{g} / \mathrm{g}$ (average $0.75 \pm 0.57 \mu \mathrm{g} / \mathrm{g}$ ). Regarding organochlorine pesticides, the highest level was recorded by $p, p^{\prime}$-DDE $(6.76 \pm 1.21 \mathrm{ng} / \mathrm{g} / \mathrm{dry}$ weight $)$, followed by

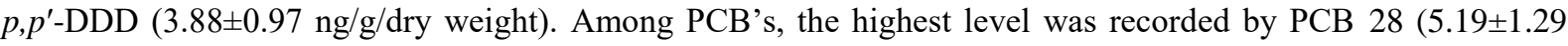
$\mathrm{ng} / \mathrm{g} / \mathrm{dry}$ weight). The results of this study revealed that heavy metals, pesticides and polychlorinated biphenyls values identified in anchovy tissue, species of commercial interest from the Black Sea, are not threatening to human consumers.
\end{abstract}

Keywords: heavy metals, organochlorine pesticides (OCPs), polychlorinated biphenyl (PCBs), Black Sea, anchovy.

\section{Introduction}

In recent decades, pollution has become one of the major threats for humanity [1]. The marine environment did not remain unaffected. This situation arose mainly as a result of the anthropogenic discharges into the marine environment and many species are threatened by these influences.

Since the worldwide population increased rapidly over the past decades this fact has caused a fast augmentation of demand for aquatic sources of food, mainly fish, originating from fisheries.

Approximately $70 \%$ of the global fish catches are used to satisfy the population's demand for food. In 2011, the global fish consumption per capita was estimated around $18.9 \mathrm{~kg}$ and in 2012 around $19.2 \mathrm{~kg}$ [2]. In Romania, fish consumption per capita reached
$4 \mathrm{~kg}$ in 2012 and $4.5-5 \mathrm{~kg}$ in 2014 and it is continuously growing [3] (Figure 1). Thus, performing analyses on the pollutants bioaccumulation in marine organisms, especially fish and seafood, has become increasingly necessary to ensure safe food for the population.

Among the most frequently identified pollutants in sea water and sediments, but also in biota are heavy metals, organochlorine pesticides (OCPs) and polychlorinated biphenyls (PCBs).

Knowing the state of accumulation of heavy metals in marine organisms is of special importance, with implications in areas as diverse as environmental and public health standards and monitoring compliance with the environmental risk assessment [4].

\footnotetext{
* Corresponding author. E-mail address: madalina.galatchi@yahoo.com (M. Galaţchi)
} 


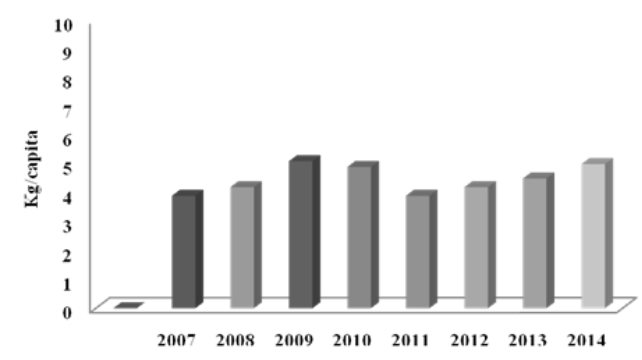

Figure 1. The annual average consumption of fish and fish products in Romania [3]

Heavy metal contamination of coastal areas can be correlated directly with urban or industrial sources. Also, the influence of rivers is significant on coastal areas, these are a major source of metals, especially in particulate form, extreme hydrological events (floods) contributes to enhancing this contribution. Atmospheric metal flows, demonstrating both natural influences and human, are also considered to be an important, both in coastal and basin and depend on local weather variability and climate statistics [5].

Due to all these factors, concentrations of heavy metals in sea water are significantly influenced by spatial (depth, proximity to the mouth of the river or the source of contamination) and temporal (season) variations. The coastal sediments present a degree of variation lower than in the water column. However, metals are not permanently fixed in the sediment; changes in the physico-chemical parameters in the water column trigger the release of metals from sediment into the water column [6].

Metal accumulation by biota is subject to a number of physico-chemical and biological processes that determine their solubilization and bioavailability. High concentrations of metals in the environment affect biota by their ability to bioaccumulation, transferring the food chain and goes ultimately to human consumers.

The distribution of heavy metals in sediments and marine shellfish along the Romanian Black Sea coast has highlighted differences between different sectors of the coastline, generally seen in the concentrations slightly increased in certain coastal areas subject to different anthropogenic pressures, and the marine area under the influence of the Danube [7].

The presence of organochlorine pesticides in Black Sea water was correlated with their uncontrolled use in agriculture in the last decades. Their action on marine organisms depends on their chemical formula and on the degree of their persistence.

As the knowledge of the level of pollutants in marine biota is very important to human food safety, this study presents data on the degree of contamination with pollutants of a fish species among the most consumed around the Black Sea basin.

\section{Materials and methods}

The monitoring of pollutants in recent years in Romanian Black Sea waters was performed by seasonally analyzing samples of seawater, surface sediment and biota, collected along the shoreline, from a network of about 40 stations, located on the 5$60 \mathrm{~m}$ bathymetric strip.

The analytical determination of heavy metals [8] - copper, cadmium, lead, nickel and chromium was performed by graphite furnace atomic absorption spectrometry (GF-AAS) using a SOLAAR M6 DUAL Zeeman, Thermo Electron - UNICAM. Pretreatment consists in the following stages: biological samples were freeze-dried, homogenized, weighed and subjected to digestion with $5 \mathrm{ml}$ nitric acid $\left(\mathrm{HNO}_{3} 65 \%\right.$, Suprapur Merck) in sealed Teflon vessels ( $60 \mathrm{ml}$ Savillex) on a hotplate at $120^{\circ} \mathrm{C}$. After completion of digestion, samples were brought to 100 $\mathrm{ml}$ volume with deionized water $(18.2 \mathrm{M} \Omega \mathrm{cm}$, Millipore). In the solutions obtained after the digestion of samples, metals (copper, cadmium, lead, nickel and chromium) were analyzed using graphite furnace-atomic absorption spectrometry. The accuracy and precision of the analytical method were checked with certified reference materials. The determined values were analyzed in relation to the values recommended by EC Regulation No. 1259/2011 [9] that sets allowable concentrations of some heavy metals in fish $(0.3 \mu \mathrm{g} / \mathrm{g}$ sp Cd and 0.3 $\mu \mathrm{g} / \mathrm{g} \mathrm{sp} \mathrm{Pb})$.

In order to determine the organochlorine pesticides (OCPs) and polychlorinated biphenyls (PCBs), the frozen tissues were freeze-dried and homogenized. About $3 \mathrm{~g}$ of the dried tissue were used for analysis. Internal standard 2,4,5-trichlorobenzene was added to the samples for quantifying the overall recovery of the analytical procedures. The extraction of OCPs and PCBs from biota samples was done with $30 \mathrm{ml}$ acetone/hexane $(1: 1, \mathrm{v}: \mathrm{v})$, in microwave extraction system Start E Milestone for $30 \mathrm{~min}$ at $120^{\circ} \mathrm{C}$. Further processing of the samples followed the steps: concentration of the extracts to rotary evaporator, clean-up on florisil, respectively, alumina/silica column and concentration of the samples using the Kuderna-Denish concentrator and nitrogen flow. The analytical determination of the OCPs and PCBs $[10,11]$ content was made by the gas-chromatographic method with a Perkin Elmer gas chromatograph CLARUS 500, equipped with electron capture detector. The analyzed compounds were $\mathrm{HCB}$, lindane, heptachlor, aldrin, dieldrin, endrin, $\quad p, p^{\prime}$-DDE (dichlorodiphenyldichloroethylene), $\quad p, p^{\prime}$-DDD (dichlorodiphenyldichloroethane) and $p, p^{\prime}$-DDT (dichlorodiphenyltrichloroethane), PCB 28, PCB 52, PCB 101, PCB 138, PCB 118, PCB 153 and PCB 180.

For statistical interpretation, in order to determine significant differences, the means values were analyzed using paired Student T-test. 
For heavy metal determination, anchovy samples were collected from stationary fishing points $(10 \mathrm{~m}$ depth) located in five areas of the Romanian Black Sea coast (from north to south: Station 1 - Cape Midia, Station 2 - Mamaia, Station 3 - Costinesti, Station 4 - 2 Mai, Station 5 - Vama Veche) (Figure 2a). These are the major fishing areas in which were recorded in recent years a growing presence of anchovy in the catches.

Initially, the study started with the purpose of assessing the bioaccumulation of heavy metals in the tissue of anchovies, subsequently, the need for detailed examination led us to make determinations also for other elements of risk for the human population.

Such as, for organochlorine pesticide (OCP) and polychlorinated biphenyl (PCB) determinations, anchovy samples were collected also from stationary fishing points, but located in three areas of the Romanian Black Sea coast (Station 1 - Cape Midia, an industrialized area, Station 2 - Mamaia, a well developed touristic area, and Station 3 - Olimp, a formerly well developed touristic area) (Figure 2b).
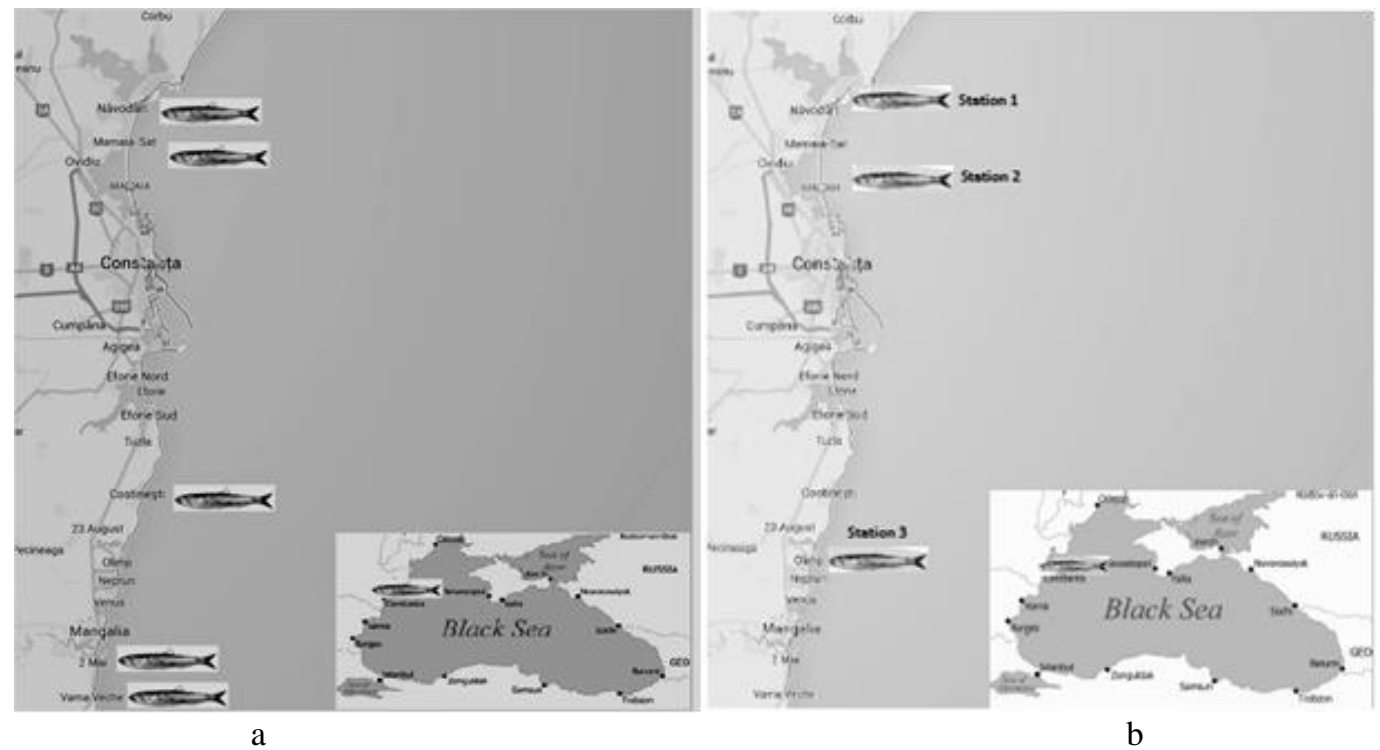

Figure 2. Map of heavy metal sampling stations (a) and map of OCPs and PCBs sampling stations (b) for European anchovy

The sampling stations have been selected taking into account also, the degree of contamination identified, prior to the study, in other marine organisms [20].

\section{Results and discussion}

Regarding the heavy metals concentrations in marine waters, the environmental status of Romanian Black Sea waters was estimated based on the proposed target values for defining good status (GES) under the Marine Strategy Framework Directive. Environmental quality standards for heavy metals in marine waters are from European or national legislation - Order No. 161/2006 [12] for elements not included in the European Directive. As such, except for cadmium, for which a slight exceeding was observed in the northern sector (in 2013), the annual average values for all elements investigated in the last years did not exceed the proposed target values [7]. In terms of biota, in recent years studies have been conducted on mollusks and fish. Thus, the distribution of heavy metals in marine mollusks highlighted differences between different sectors of the coastline, generally observing slightly increased concentrations in certain coastal areas subject to different anthropogenic pressures (ports, discharges wastewater), and in the marine area under the influence of the Danube [7]. The hydrographic basin of the Danube includes more than 1,000 industrial sites, agricultural and stock raising units and localities with a major impact on water resources [13].

In terms of heavy metals in fish, the mean values and standard deviations identified in the muscle tissue of anchovy are shown in Table 1.

As shown in the above table, the elements that have exceeded the allowed levels under the EU legislation $(0.30 \mu \mathrm{g} / \mathrm{g})$ are cadmium and lead in 2010 , but for 2013 the recorded values are well below the maximum level. The values highlighted in dark color are values exceeding the limits allowed by law and the values highlighted in light gray are values close to the maximum allowable level. 
M. GALATCHI et al. / Ovidius University Annals of Chemistry 28 (2017) 11 - 17

Table 1. Heavy metal concentrations in anchovy (Romanian Black Sea coast) tissue in 2010 and 2013

\begin{tabular}{ccccccc}
\hline & Station & $\begin{array}{c}\mathbf{C d} \\
(0.3 \mu \mathrm{g} / \mathrm{g})^{*}\end{array}$ & $\begin{array}{c}\mathbf{P b} \\
(0.3 \mu \mathrm{g} / \mathrm{g})^{*}\end{array}$ & $\begin{array}{c}\mathbf{N i} \\
\mu \mathrm{g} / \mathrm{g}\end{array}$ & $\begin{array}{c}\mathbf{C r} \\
\mu \mathrm{g} / \mathrm{g}\end{array}$ & $\begin{array}{c}\mathbf{C u} \\
\mu \mathrm{g} / \mathrm{g}\end{array}$ \\
\cline { 2 - 7 } $\mathbf{2}$ & Cape Midia & $0.52 \pm 0.07$ & $1.62 \pm 0.24$ & $1.13 \pm 0.16$ & $1.62 \pm 0.27$ & $5.24 \pm 0.78$ \\
$\mathbf{0}$ & Mamaia & $0.35 \pm 0.05$ & $1.03 \pm 0.17$ & $0.13 \pm 0.02$ & $0.32 \pm 0.05$ & $5.76 \pm 1.03$ \\
$\mathbf{1}$ & Costineşti & $0.29 \pm 0.04$ & $0.35 \pm 0.06$ & $0.27 \pm 0.04$ & $0.44 \pm 0.06$ & $3.96 \pm 0.59$ \\
$\mathbf{0}$ & $\mathbf{2}$ Mai & $0.31 \pm 0.05$ & $0.34 \pm 0.05$ & $0.21 \pm 0.03$ & $0.45 \pm 0.08$ & $4.29 \pm 0.72$ \\
& VamaVeche & $0.32 \pm 0.04$ & $0.29 \pm 0.04$ & $0.21 \pm 0.03$ & $0.19 \pm 0.02$ & $3.63 \pm 0.65$ \\
\hline & Cape Midia & $0.04 \pm 0.01$ & $0.08 \pm 0.02$ & $0.18 \pm 0.04$ & $0.21 \pm 0.04$ & $2.01 \pm 0.33$ \\
$\mathbf{2}$ & Mamaia & $0.03 \pm 0.02$ & $0.07 \pm 0.02$ & $0.09 \pm 0.01$ & $0.05 \pm 0.02$ & $1.83 \pm 0.36$ \\
$\mathbf{0}$ & Costineşti & $0.08 \pm 0.01$ & $0.13 \pm 0.03$ & $0.03 \pm 0.01$ & $0.10 \pm 0.02$ & $0.58 \pm 0.09$ \\
$\mathbf{1}$ & $\mathbf{2 ~ M a i}$ & $0.11 \pm 0.03$ & $0.10 \pm 0.01$ & $0.08 \pm 0.02$ & $0.02 \pm 0.01$ & $0.83 \pm 0.13$ \\
$\mathbf{3}$ & VamaVeche & $0.11 \pm 0.01$ & $0.08 \pm 0.02$ & $0.02 \pm 0.01$ & $0.02 \pm 0.01$ & $0.57 \pm 0.14$ \\
\hline
\end{tabular}

*EC Regulation No. 1881/2006 (amended in 2007, 2008, 2010)

By applying the paired Student T-test we can statistically observe significant differences $(\mathrm{p}<0.05)$

between $\mathrm{Cd}$ and $\mathrm{Pb}$ mean values for the two study periods (Table 2).

Table 2. Differences between mean values for $\mathrm{Cd}$ and $\mathrm{Pb}$ identified in anchovy tissue, samples from Romanian Black Sea waters (2010 and 2013)

\begin{tabular}{ccc:cc}
\hline & $\mathbf{C d}(\mu \mathrm{g} / \mathrm{g})$ & $\mathbf{C d}(\mu \mathrm{g} / \mathrm{g})$ & $\mathbf{P b}(\mu \mathrm{g} / \mathrm{g})$ & $\mathbf{P b}(\mu \mathrm{g} / \mathrm{g})$ \\
\cline { 2 - 5 } & $\mathbf{2 0 1 0}$ & $\mathbf{2 0 1 3}$ & $\mathbf{2 0 1 0}$ & $\mathbf{2 0 1 3}$ \\
\hline Mean & 0.358 & 0.074 & 0.746 & 0.092 \\
Variance & 0.00867 & 0.00143 & 0.32623 & 0.00057 \\
Observations & 5 & 5 & 5 & 5 \\
$\mathbf{t}$ Stat & 6.31892 & & 2.55812 & \\
$\mathbf{P}(\mathbf{T}<=t)$ one-tail & 0.00073 & & 0.03138 & \\
$\mathbf{t}$ Critical one-tail & 2.01505 & & 2.13185 & \\
$\mathbf{P}(\mathbf{T}<=t)$ two-tail & $\mathbf{0 . 0 0 1 4 6}$ & & $\mathbf{0 . 0 4 2 7 6}$ & \\
$\mathbf{t}$ Critical two-tail & 2.57058 & & 2.77645 & \\
\hline
\end{tabular}

The heavy metal levels in various types of living organism from the Black Sea Turkish coast have been also investigated by several researchers [14-18]. The results for heavy metal mean values and standard deviations in anchovy from the Black Sea Turkish coast investigated in the last years are summarized in Table 3 .

Table 3. Some heavy metal mean values in anchovy tissue from Turkish Black Sea coast (adapted from [14])

\begin{tabular}{ccccc}
\hline \multirow{2}{*}{$\begin{array}{c}\text { Heavy metals } \\
\boldsymbol{\mu} \text { g/g s.p. }\end{array}$} & Uluozlu et al. [15] & Tüzen [16] & Turan et al. [17] & Nisbet et al. [18] \\
\cline { 2 - 5 } Cd & $0.65 \pm 0.04$ & $0.27 \pm 0.02$ & $0.124 \pm 0.018$ & $0.035 \pm 0.05$ \\
$\mathbf{P b}$ & $0.33 \pm 0.01$ & $0.30 \pm 0.02$ & $0.329 \pm 0.302$ & $0.70 \pm 0.07$ \\
$\mathbf{Z n}$ & $40.2 \pm 3.2$ & $38.8 \pm 3.2$ & $25.41 \pm 3.664$ & $26.25 \pm 1.67$ \\
$\mathbf{C u}$ & $0.95 \pm 0.04$ & $1.96 \pm 0.14$ & - & $2.73 \pm 0.21$ \\
\hline
\end{tabular}

It can be observed in Table 3 that the elements that have exceeded the level determined under the EU legislation are also cadmium and lead for the anchovies analyzed from Turkish Black Sea waters. 
Regarding the differences between the mean values for $\mathrm{Cd}, \mathrm{Pb}$ and $\mathrm{Cu}$ identified in anchovy tissue, in 2010, the paired Student T-test was applied and the differences between the values identified in Romanian waters Black Sea are statistically slightly different $(p>0.05)$ compared those identified in Turkish Black Sea waters (Table 4).

Table 4.The similarity between the mean values for some heavy metals $(\mathrm{Cd}, \mathrm{Pb}, \mathrm{Cu})$ identified in anchovy tissue, samples from Romanian and Turkish Black Sea waters in 2010

\begin{tabular}{|c|c|c|}
\hline & $\begin{array}{c}\text { Romanian Black } \\
\text { Sea waters } 2010\end{array}$ & $\begin{array}{c}\text { Turkish Black } \\
\text { Sea waters } \\
2010 \\
\end{array}$ \\
\hline Mean & 1.96 & 1.26 \\
\hline Variance & 5.9601 & 1.6513 \\
\hline Observations & 3 & 3 \\
\hline t Stat & 0.43947 & \\
\hline $\begin{array}{c}P(T<=t) \text { one- } \\
\text { tail }\end{array}$ & 0.34503 & \\
\hline $\begin{array}{l}\text { t Critical one- } \\
\text { tail }\end{array}$ & 2.35336 & \\
\hline $\begin{array}{c}\text { P }(T<=t) \text { two- } \\
\text { tail }\end{array}$ & 0.69005 & \\
\hline $\begin{array}{c}\text { t Critical two- } \\
\text { tail }\end{array}$ & 3.18245 & \\
\hline
\end{tabular}

Fish are considered good indicators for the heavy metal concentration in aquatic ecosystems because they occupy different trophic level [14].

Concerning other elements investigated, $\mathrm{Cu}, \mathrm{Ni}$ and $\mathrm{Cr}$, the recorded values din not exceed the suggested target values for the achievement of a good ecological status: $6 \mu \mathrm{g} / \mathrm{L} \mathrm{Cu}, 34 \mu \mathrm{g} / \mathrm{L} \mathrm{Ni}, 20 \mu \mathrm{g} / \mathrm{L} \mathrm{Cr}$ [7].

Regarding organochlorine pesticides, in recent years the highest concentrations in water were identified for HCB and lindane. Compared with threshold values proposed for water in order to define good environmental status, frequent exceedances were identified for lindane, cyclodienes (aldrin, dieldrin, endrin) and DDT (DDT and metabolites) [7]

The organochlorine pesticides levels identified in anchovy tissue are presented in Figure 3. As shown, the pesticides with the highest concentration are $p, p^{\prime}$ DDE, lindane and heptachlor. Regarding the sampling areas of anchovy, it was observed that in samples collected from the Olimp station was identified the highest level of $p, p^{\prime}$-DDE $(6.76 \pm 1.21$ ng/g/dry weight), followed by $p, p^{\prime}$-DDD $(3.88 \pm 0.97$ $\mathrm{ng} / \mathrm{g} / \mathrm{dry}$ weight) and in the Mamaia station high levels were recorded for the majority of pesticides analyzed (lindane $5.15 \pm 1.28 \mathrm{ng} / \mathrm{g} /$ dry weight, heptachlor $4.70 \pm 0.85 \mathrm{ng} / \mathrm{g} / \mathrm{dry}$ weight, dieldrin $3.26 \pm 0.54 \mathrm{ng} / \mathrm{g} / \mathrm{dry}$ weight).

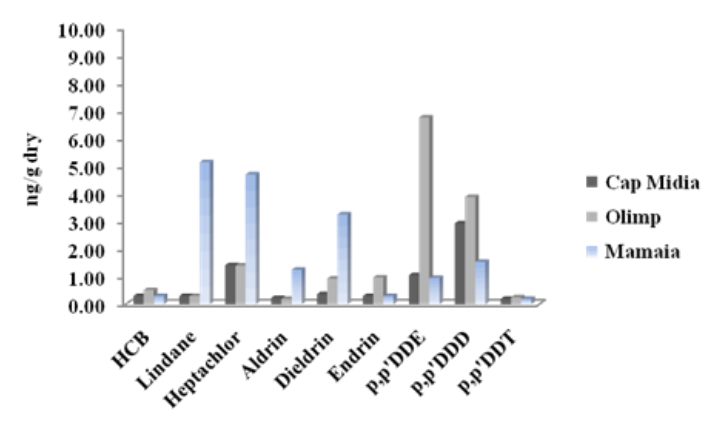

Figure 3. Organochlorine pesticide levels identified in anchovy tissue in 2015

Even though there are not yet threshold values proposed by EU legislation for defining the good ecological status for organochlorine pesticides in terms of biota, the national legislation in force, Order 147/2004 [19], regulates the maximum levels of pesticides (in fish, fishery products, eggs, crustaceans, mollusks, cephalopods). Concentrations of organochlorine pesticides (OCPs) in fish (pelagic species like sprat) were determined in 2012-2013 and the values were lower than the maximum admissible levels. The dominant compounds in fish were represented by DDT and its metabolites (the isomers DDD and DDE) [20] similarly to the identified values in anchovy.

PCBs were also analyzed in anchovy tissue. Polychlorinated biphenyls (PCBs) are toxic chemical compounds belonging to the class of persistent organic pollutants (POPs). They were produced in many industrialized countries, being used in transformers and capacitors due to their dielectric and thermal insulation. Later research has shown that PCBs have negative impact on human health and environmental quality (carcinogenicity, reproductive function disorders, immune system changes, loss of biological diversity). The production of equipment containing PCBs was banned since the 1970s, but in some countries it is currently still in use.

The levels of PCBs identified in anchovy tissue are presented in Figure 4.

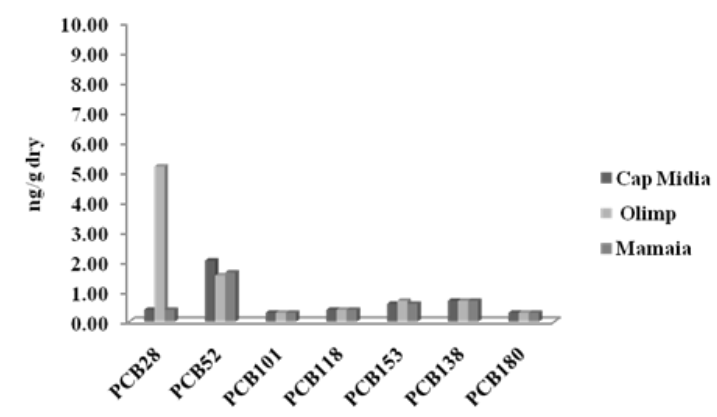

Figure 4. Polychlorinated biphenyl levels identified in anchovy tissue in 2015 
The level of polychlorinated biphenyls identified in anchovy tissue was similar in all the analyzed stations, but it can be noticed that in the Olimp station was identified the highest level of PCB 28 (5.19 \pm 1.29 $\mathrm{ng} / \mathrm{g} / \mathrm{dry}$ weight). This situation was also found in other marine organisms, mollusks. Higher values may be related to the fact that in Olimp area the tourism was practiced extensively in the years 80'-90' and now the area is abandoned, is not subject to any type of analysis and control.

The pollutants bioaccumulation in anchovy from Romanian Black Sea coast has highlighted differences between some stations, generally seen in the concentrations slightly increased in certain coastal areas.

\section{Conclusions}

The results presented in this study shows that the heavy metal levels identified in anchovy tissue that exceeded the allowed levels under the EU legislation are cadmium and lead in 2010 at Romanian Black Sea coast, in some samples, and for 2013 the recorded values were well below the maximum allowable level. Thus, there is an improvement in the marine environment on the presence of heavy metal, smaller values were identified also in other marine organisms.

The values obtained for the two study periods, 2010 and 2013 in the Romanian Black Sea waters were significant differences ( $\mathrm{p}<0.05$ ) only for $\mathrm{Cd}$ and $\mathrm{Pb}$, other values were similar.

Regarding the differences between the mean values for $\mathrm{Cd}, \mathrm{Pb}$ and $\mathrm{Cu}$ identified in anchovy tissue, Romanian and Turkish Black Sea samples, in 2010, it was revealed that the values are similar.

Among the organochlorine pesticides that were identified in anchovy tissue, the pesticides with the highest value were $p, p^{\prime}$-DDE, lindane and heptachlor. Regarding the sampling areas of anchovy, it was observed that in samples collected from Olimp station was identified the highest level of $p, p^{\prime}$-DDE, followed by $p, p^{\prime}$-DDD, and in the Mamaia station were recorded high levels for the majority of pesticides analyzed. However, the organochlorine pesticides levels were below the maximum values allowed by national legislation [19].

Regarding the level of polychlorinated biphenyls identified in anchovy tissue, it can be noticed that it was similar in all the analyzed stations, but, in the Olimp station, was identified the highest level of PCB 28.

Long term investigations on several marine species from the Romanian Black Sea coast will allow highlighting certain aspects of the process of bioaccumulation of pollutants and their potential trophic transfer, information contributing to enhancing the knowledge in the field and creating the basis for future research.

\section{Acknowledgments}

This research was completed within the $\mathrm{PhD}$ research program of the Doctoral School of Applied Sciences, "Ovidius" University of Constanta, Romania, with the full support of colleagues from NIMRD "Grigore Antipa" Constanta, Romania.

\section{Conflict of interests}

The authors declare that there is no conflict of interests.

\section{References}

[1]. L.D. Galaţchi, The Romanian national accidental and intentional polluted water management system, in "Management of Intentional and Accidental Water Pollution", NATO Security through Science Series, Dordrecht - The Netherlands, 181-184 (2006).

[2]. FAO, Fish to 2030 - Prospects for Fisheries and Aquaculture, Agriculture and Environmental Services Discussions Paper 3: 44-47 (2013).

[3]. National Institute of Statistics, Statistical Yearbook 2015 (in Romanian). (http://www.insse.ro/cms/files/Anuar\%20statist ic/04/04\%20Veniturile \%20cheltuielile $\% 20$ si $\%$ 20consumul\%20populatiei_ro.pdf).

[4]. UNEP, Contaminant monitoring programs using marine organisms: quality assurance and good laboratory practice. Reference Methods for Marine Pollution Studies, 57: 1-23 (1990).

[5]. A. Oros, M.T. Gomoiu, A review of metal bioaccumulation levels in the Romanian Black Sea biota during the last decade - A requirement for implementing marine strategy framework directive (Descriptors 8 and 9), J. Environ. Prot. Ecol. 13 (2012) 1730-1739.

[6]. W.X. Wang, N.S. Fisher, Modeling metal bioavailability for marine mussels, Rev. Environ. Contam. Toxicol. 151 (1997) 38-39.

[7]. Environmental State Report, Report on the state of the marine and coastal environment in 2013, Marine Research (Cercetări Marine) 44 (2014) 5-35.

[8]. IAEA-MEL, Standard Operating Procedures for Trace Metals Analyses, 1999.

[9]. European Commission Regulation No. 1259/2011 amending Regulation (EC) No. $1881 / 2006$ as regards maximum levels for dioxins, dioxin-like PCBs and non dioxin-like PCBs in foodstuffs, Official journal of the European Union, L 320, 3 December 2011, 1823.

[10]. IAEA-MEL, Training manual on the measurement of organochlorine and petroleum hydrocarbons in environmental samples, Marine Environmental Studies Laboratory (1995).

[11]. M.I. Nenciu, V. Coatu, A. Oros, D. Rosioru, D. 
Tiganus, N. Rosoiu, Pollutant bioaccumulation in the Long-Snouted Seahorse at the Romanian Coast, J. Environ. Prot. Ecol. 4 (2014) 16501659.

[12]. Order No. 161/2006 for approving the norms concerning the classification of surface water quality in order to establish the good ecological status of water bodies. Official Journal, 161 of 16 February, 2006.

[13]. L.D. Galaţchi, Environmental Risk Assessment, in "Chemicals as Intentional and Accidental Global Environmental Threats", Science Series - C: Environmental Security, Springer, Dordrecht - The Netherlands, 1-6 (2006).

[14]. M. Boran, I. Altinok, A review of heavy metals in water, sediment and living organisms in the Black Sea, Turk. J. Fish. Aquat. Sc. 10 (2010) 565-572.

[15]. O.D. Uluozlu, M. Tüzen, D. Mendil, M. Soylak, Trace metal content in nine species of fish from the Black and Aegean Seas, Turkey. Food Chem. 104 (2007) 835-840.

[16]. M. Tüzen, Toxic and essential trace elemental content in fish species from the Black Sea, Turkey, Food Chem. Toxicol. 47 (2009) 17851790.
[17]. C. Turan, M. Dural, A. Oksuz, B. Öztürk, Levels of heavy metals in some commercial fish species captured from the Black Sea and Mediterranean Coast of Turkey, B. Environ. Contam. Tox. 82 (2009) 601-604.

[18]. C. Nisbet, G. Terzi, O. Pilger, N. Sarac, Determination of heavy metal levels in fish sample collected from the Middle Black Sea, Kafkas Üniv. Veteriner Fak. Dergisi 16 (2010) 119-125.

[19]. Order No. 147/2004 for approving the sanitary veterinary and food safety norms on pesticide residues in animal and non-animal products and residues of veterinary drugs in animal products, Official Journal, 143 of 17 February, 2005 (in Romanian).

[20]. V. Coatu, A. Oros, D. Tiganus, L. Lazar, Assessment of chemical contamination in biota from Romanian marine waters in respect with maximum admissible levels regulated by legislation for human consumption, J. Environ. Protect. Ecol. 16 (2015) 117-125.

Received: 15.02 .2017 Received in revised form: 29.03.2017 Accepted: 5.04.2017 